\title{
Changes in Hydrological Response of Forest Conversion to Agroforestry and Rainfed Agriculture in Renggung Watershed, Lombok, Eastern Indonesia
}

\author{
Muhamad Husni Idris ${ }^{1,3^{*}}$, Mahrup ${ }^{2,3}$ \\ ${ }^{1}$ Department of Forest Science, Mataram University, Jalan Pendidikan 37 Mataram Lombok, Indonesia 83125 \\ ${ }^{2}$ Department of Soil Science, Mataram University, Jalan Majapahit 62 Mataram Lombok, Indonesia 83125 \\ ${ }^{3}$ Research Center for Water Resource and Agroclimate, Mataram University, \\ Jalan Pendidikan 37 Mataram Lombok, Indonesia 83125
}

Received January 10, 2017/Accepted August 15, 2017

\begin{abstract}
Forest is an ideal ecosystem for a hydrological cycle, however converting forests to agroforestry or rainfed agriculture is inevitable. This study elaborates a hydrological response of infiltration, runoff, and soil moisture in three land uses at Renggung watershed. Field measurements were conducted in 2014-2015 in those system with soil types of entisols at upstream, inceptisols at the middle, and vertisols at downstream. Results showed that constant infiltration rate at upstream in forest was $55.6 \mathrm{~cm} \mathrm{hr}^{-1}$, in 15-30 years agroforestry was $32.4 \mathrm{~cm} \mathrm{hr} r^{-1}$ on average and in rainfed was $26.4 \mathrm{~cm} \mathrm{hr}^{-1}$. Infiltration in agroforestry at the middle and downstream was $16.8 \mathrm{~cm} \mathrm{hr}^{-1}$ and $11.2 \mathrm{~cm} \mathrm{hr} r^{-1}$, respectively, while in rainfed was $2.4 \mathrm{~cm} \mathrm{hr}^{-1}$ and $4.8 \mathrm{~cm} \mathrm{hr}^{-1}$. Runoff at upstream with $29.3 \mathrm{~mm} \mathrm{hr}^{-1}$ rainfall in forest was zero, in agroforestry was $0.026 \mathrm{~mm} \mathrm{hr}^{-1}$ and in rainfed was $0.071 \mathrm{~mm} \mathrm{hr}^{-1}$. Runoff in agroforestry at the middle and downstream with $37.1 \mathrm{~mm} \mathrm{hr}^{-1}$ and $23.8 \mathrm{~mm} \mathrm{hr}^{-1}$ rainfall were $0.045 \mathrm{~mm} \mathrm{hr}^{-1}$, and $0.026 \mathrm{~mm} \mathrm{hr}^{-1}$. There was a half and one third of that in rainfed. Soil water content in successive order from high to low was in forest, agroforestry, and rainfed. So, capacity of agroforestry in sustaining the hydrology cycle was in between forests and rainfed agriculture.
\end{abstract}

Keywords:land use, deforestation, infiltration, runoff, soil water

*Correspondence author,email:mhidris@unram.ac.id; tel. +62-370-622862,fax: +62-370-638265

\section{Introduction}

It has been no doubt that tropical forests play an important role in a hydrological cycle (Bruijnzeel 2004) as well as climate change (Chramer et al. 2004; Bush et al. 2015; Lawrence et al. 2015). However, deforestation and forest degradation due to over logging and forest conversion in tropical areas are inevitable. In most developing country such as Indonesia, deforestation and forest degradation is affected by many factors including economic interest, population growth and unclear land tenure (Indarto et al. 2012). Deforestation and forest degradation in tropical areas still continue at a certain rate, although there have been strong commitment from governments to minimize it. During the period of 2000-2010 deforestation in the tropical area was estimated at a rate of 6 million ha year ${ }^{-1}$ (Achard et al. 2014).

In Indonesia, communities living surrounding forest may have right to manage forest nearby, under Community Forest Management Unit policy. This policy is considered as an alternative solution to directly deliver socio-economic function of forests for improving the prosperity of local communities and at the same time, they take responsibility to maintain the ecological function of forests (Bowler et al. 2010). Porter-Bolland et al. (2012) showed that community- based forest management presented lower annual deforestation compared to that of protected area. However, the activity of communities inside the forest, for example in the tropical forest, in Indonesia, often change natural forest cover to agroforestry system or even agricultural land to some extent. In Indonesia, community forest also participate in protecting forests (Kaskoyo et al. 2014), although, the community tend to change natural trees to fruit trees or multipurpose tree species which are considered to be more economically beneficial.

Long term human activities (anthropogenic factor) inside forests possibly alter characteristics of soils and land cover. The soil characteristics that may change includes soil structure, bulk density, soil organic matter (Hajabbasi et al. 1997; Price et al. 2010; Agnese et al. 2011; Pirastru et al. 2013). Land cover change from lowland tropical forests to tree cash crop plantation such as palm oil, rubber, and cacao practising agroforestry also could also decrease soil organic carbon up to $50 \%$, particularly in the top soil (Straaten et al. 2015). These changes may affect hydrological response indicating by changing in infiltration rate, runoff, erosion, and sediment (Moehansyah et al. 2002; George et al. 2013; Shit et al. 2014; Suryatmojo 2014; Mahmoud \& Alazba 
2015). Though, it is not easy to draw the same conclusion on the effect of land use change on soil properties as well as hydrological response to that change. Afforestation and replanting trees in the tropic region increase infiltration. There was still severely lack of knowledge on infiltration rate under different edaphic condition and species effect (Ilstedt et al. 2007). Therefore, more reports from the diverse area with specific local characteristics will enhance current data and information related to the impact of land use change on the hydrological response.

This study had elaborated hydrological response of land use conversion from forest to community forest (agroforestry) and rainfed agriculture at Renggung watershed in Lombok, Eastern Indonesia.

\section{Methods}

Site description Field measurements were carried in three different land use systems, namely, natural forest, agroforestry, and rainfed agriculture at upper stream $\left(\right.$ E116 ${ }^{\circ}$ $\left.22^{\prime} 51^{\prime \prime}, \mathrm{S}^{\circ} 32^{\prime} 7^{\prime \prime}\right)$, and in two land use systems, namely agroforestry and rainfed agriculture at the middle stream (E116 20' 55', S8 41' 48") and downstream (E116 $21^{\circ} 1^{\prime} 11^{\prime \prime}$, $\left.\mathrm{S}^{\circ} 45^{\prime} 16^{\prime \prime}\right)$ of Renggung watershed (Figure 1). Field works were carried out from June 2014 to March 2015. Soil types of the sites (Soil Survey Staff 2014); in the upper, middle, and downstream were entisols, inceptisols, and vertisols respectively. The soil profile taken from the infiltration measurement site is presented in Figure 2. Soil surface of measurement sites in the forest, agroforestry, and rainfed rice field was covered by grass with variation in density along catchment. Grass population was dense in upper stream and getting lower in the middle and downstream. Dominant wood trees in the forest site were Mahagony with a density of 10 trees $100 \mathrm{~m}^{-2}$, while on agroforestry at upper, middle and down sites consisted of combination between trees and multi-purpose tree species with the density of 10-15trees $100 \mathrm{~m}^{-2}$. Meanwhile, vegetation on rainfed agriculture was seasonal cash crops.

Roots of seasonal crops were found abundance in the first layer and the root density decreased to the second layer. Roots of trees were found up to $100 \mathrm{~cm}$ soil depth. In the upstream site, it seems that pumice stone was dominant and it was found from upper layer to more than $100 \mathrm{~cm}$ depth. The pumice stone with a large size was deposited in the third layer, below $40 \mathrm{~cm}$.

Annual average rainfall at Renggung watershed was 2,550 $\mathrm{mm}$ at upper stream, 1,440 $\mathrm{mm}$ at middle stream, and $1,290 \mathrm{~mm}$ at downstream. Climate type according to Schmid Fergusson was type $\mathrm{C}$ at the upper, type $\mathrm{D}$ at the middle, and type $\mathrm{E}$ at downstream (As-syakur 2009).

Measurement of infiltration, runoff and soil moisture Hydrological data were regularly measured at each different land uses included infiltration rate, runoff and soil water content. Undisturbed soil samples were collected for bulk density, specific soil density, soil texture and soil organic matter.

Infiltration rate was measured by double-ring method (Lili et al. 2008) using a double ring infiltrometer. Measurement was directly carried out in the fields. A portable double ring infiltrometer consists of two drum cylinders with $60 \mathrm{~cm}$ in diameter of outer ring and $30 \mathrm{~cm}$ in diameter of the inner ring. Both rings were $50 \mathrm{~cm}$ height. The double ring infiltrometer were installed as follows: inner ring was firstly inserted into soil to $25 \mathrm{~cm}$ depth and about $25 \mathrm{~cm}$ was left on the soil surface. The outer ring was then adjusted and firmly inserted to enclose the inner ring with similar depth. Water was filled into the inner and outer rings. Water level drop in the inner ring was thoroughly measured during a period measurement.
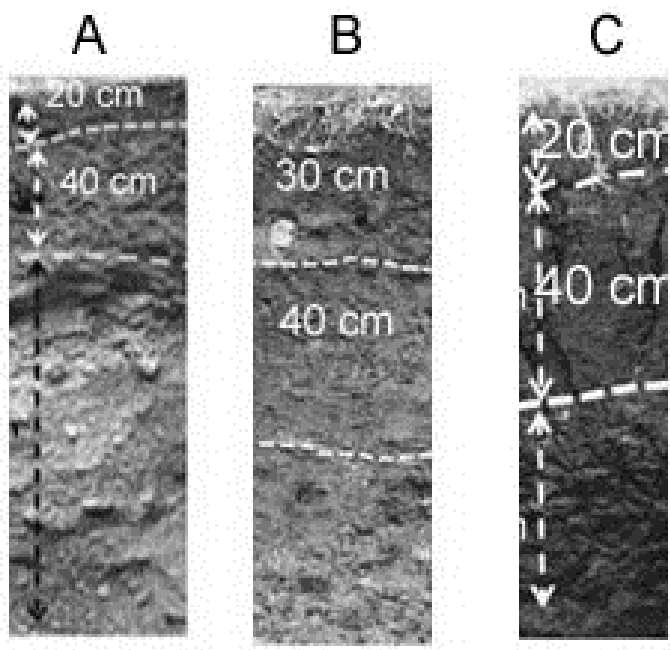

Figure 2 Soil profile in gray color of study site in the upstream (A), middle stream (B) and downstream $(\mathrm{C})$.
Figure 1 Study area in Renggung Watershed of Lombok Island, eastern Indonesia. 
A constant infiltration rate $(f \mathrm{c})$ was determined by using Horton infiltration model (Horton 1941).

$f(t)=f c+(f o-f c) e^{-k t}$

Note: $\mathrm{f}(\mathrm{t})=$ infiltration capacity $\left(\mathrm{mm} \mathrm{h}^{-1}\right)$ at time $\mathrm{t}($ hour $), f_{o}=$ initial infiltration capacity $\left(\mathrm{mm} \mathrm{h}^{-1}\right), f_{c}=$ the infiltration capacity at final equilibrium $\left(\mathrm{mm} \mathrm{h}^{-1}\right), k=$ a recession constant

In the forest area, infiltration measurement was carried out in a 50 years of the mahagony forest with the density of 10 trees $100 \mathrm{~m}^{-2}$. In agroforestry at upstream, it was measured at three sites, namely agoroforestry-1, agroforestry-2, and agroforestry- 3 where these were managed by farmers for $10-15$ years, $15-30$ years, and $>30$ years, respectively.

Runoff was measured at all plots during rainy days in rainy season from December 2014 to March 2015. Runoff was measured by collecting excess water flowing out from an isolated plot of $3 \mathrm{~m} \times 5 \mathrm{~m}$. Along circumference of the squre plot was isolated by a bund made of bamboo sealed with clay soil of $15 \mathrm{~cm}$ high and $15 \mathrm{~cm}$ wide to prevent water entering the plot. A plastic container equipped with a plastic hose of $0.5 \mathrm{~m}$ long, and $2.5 \mathrm{~cm}$ in diameter was connected to the outlet of the run off plot. The container was only collect water out from the outlet during measurement which was carried out during rainfall event. Rainfall was daily measured as well as within a period of run off measurement in 24 hours, by using an ombrometer.

Soil moisture contents were measured on each 10 days interval by taking soil samples using a soil borer from two different depths; $0-20 \mathrm{~cm}$ and $20-40 \mathrm{~cm}$. Sampling points for next 10 days measurement was about $100 \mathrm{~cm}$ apart from previous sampling points. Soil moisture contents were determined by using a gravimetric method in Soil Laboratory, Agriculture Faculty of Mataram University.

Measurement of soil properties Measurement of soil properties included soil bulk density, specific density, soil structure, soil texture, and soil organic matter. Soil bulk density was volumetrically measured using undisturbed soil samples. Soil texture was measured using a sedimentation method, and soil organic matter was measured using Walkey \& Black method. Composite soil samples for bulk density, specific density, soil structure, soil texture, and soil organic matter were taken from $0-20 \mathrm{~cm}$ and $20-40 \mathrm{~cm}$ soil depth.

\section{Results and Discussion}

Infiltration rate and capacity Figure 3 showed infiltration rate of three different land use systems, namely forest, agroforestry and rainfed agriculture at the upper stream. As shown in Figure 3, infiltration rate and its capacity based on Horton model in forest system was higher than that of agroforestry and rainfed agriculture. Constant infiltration rate $(f \mathrm{c})$ at natural forest area was $55.6 \mathrm{~cm} \mathrm{hr}^{-1}$. It was the highest rate which could be as a reference for the non disturbed system. Infiltration rate for agroforestry-1, agroforestry-2, and agroforestry- 3 was $28.8 \mathrm{~cm} \mathrm{hr}^{-1}$ (52\% of natural forest), $30 \mathrm{~cm} \mathrm{hr}^{-1}$ (55\% of forest) and $37.8 \mathrm{~cm} \mathrm{hr}^{-1}$ ( $68 \%$ of forest), respectively (Figure 6). It is clear from these figures that constant infiltration rate $(f c)$ in agroforestry system could reach infiltration rate of natural forest after a long-term practice of agroforestry. However, infiltration rate at rainfed agriculture was $26.4 \mathrm{~cm} \mathrm{hr}^{-1}$ which was $47 \%$ of infiltration rate in a natural forest. It is clear from the data that conversion from natural forest to agroforestry or rainfed agriculture could result in decreasing of infiltration rate. Wang et al. (2015) showed that infiltration in alley cropping system was significantly higher after 9 years compared to that of in monoculture system. It was also found that speed of wetting from downward movement, as well as the depth of maximum infiltration of alley cropping system, was higher than that of in the monoculture system. Concerning water management for the upper part, agroforestry could be an alternative system to sustain infiltration rate of soils. As it is seen from agroforestry-3 with $>30$ years old that infiltration rate was higher than younger agroforestry system.

Infiltration rate was also carried in a hillock system at middle stream of the watershed. Hillock system is common formation of land physiography at the middle stream. It was formerly covered by densed trees with nearly similar to forest characteristic. Nowadays, it is due to increasing of land demand for food and housing, vegetations on hillock formation have changed to agroforestry system and, in some case, it was converted to upland agriculture. Soil type was complex inceptisols (Figure 2b), soil texture was sandy clay. Roots were commonly found in the first layer $(0-30 \mathrm{~cm}$ from surface), while gravels with the diameter of $2-3 \mathrm{~cm}$ were found in the second layer (30-70 $\mathrm{cm}$ from surface), and gravels with diameter $>3-5 \mathrm{~cm}$ was deposited in the third layer ( $>70 \mathrm{~cm}$ from surface).

Infiltration rate on the hillock with agroforestry system and upland agriculture system are presented in Figure 4. It can be seen from the figure that infiltration rate on agroforestry of hillock was $16.8 \mathrm{~cm} \mathrm{hr}^{-1}$. It was higher than that of upland agriculture which was $2.4 \mathrm{~cm} \mathrm{hr}^{-1}$. A significant change of infiltration rate occurred after converting land use on hillock system to upland agriculture without annual trees. Upland agriculture could result in decreasing of soil infiltration capacity. It was because of tillage practice, removing an organic residue of agriculture crops out of land and exposure of soil surface which intensify soil erosion.

Measurement of infiltration at downstream was also carried out in agroforestry system and rainfed agriculture on vertisols. Figure $2 \mathrm{c}$ shows soil profile of vertisols at the measurement site. Vertisols was characterized by cracking when dry, and sticky as well as swelling when wet. Soil texture is clay which is dominated by montmorillonite. This causes infiltration rate very slow. Figure 5 shows infiltration rate in agroforestry and rainfed agriculture in Vertisols. It is clear from the figure that constant infiltration rate in agroforestry was higher than that of rainfed agriculture or rice field, i.e. $11.2 \mathrm{~cm} \mathrm{hr}^{-1}$ and $4.8 \mathrm{~cm} \mathrm{hr}^{-1}$, respectively. Agroforestry in vertisols maintains the soils under the unsaturated condition, deep root penetrating which allows water to easily infiltrate during the rain event. However, rainfed agriculture or rice field is commonly under flooding condition or saturated soils. Rice field experiences paddling process during land cultivation. It is to prevent water infiltrating into lower layers of the soil profile and to keep water standing (flooding) on the soil surface. This practice is 


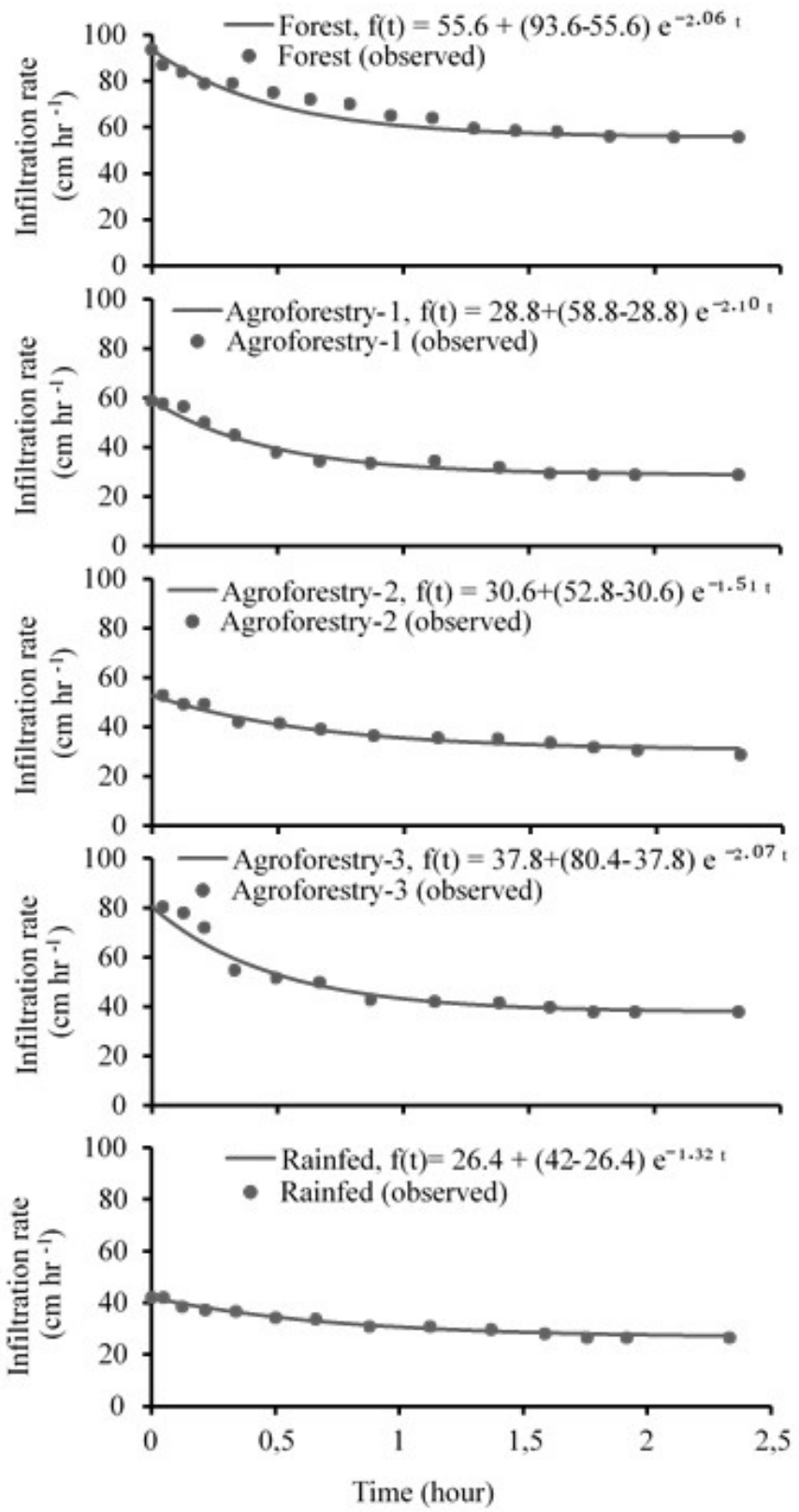

Figure 3 Observed and Hortonian Infiltration model for forest, agroforestry, and rainfed agriculture in upstream

common for rice cropping system which results in reducing infiltration capacity of soils; destroying soil structure and allowing soil compaction.

The results of this study indicate that infiltration rate for tree planting area was higher than that of rainfed agriculture for each three different soil types. Higher infiltration capacity on forest and tree covered land may attribute to soil macroporosity. Shougrakpam et al. (2010) presented that undisturbed forest soils had a high degree of soil macroporosity throughout the soil profile, in contrast, paddy fields practices could seal of macropores at the topsoil due to paddling and a hard pan formation. Change of soil organic matter due to land cover change (Hajabbasi et al. 1997; Haque et al. 2014) could also resulted in the different rate of infiltration.

Runoff Tabel 1 shows runoff for each land use at the upper stream (forest, agroforestry, and rainfed agriculture), at the middle (agroforestry and upland agriculture), and at downstream (agroforestry and rainfed agriculture). Characteristics of rainfall during runoff observation showed that intensity of rainfall during measurement was $29.2 \pm 11.2$ $\mathrm{mm} \mathrm{hr}^{-1}, 37.3 \pm 10.1 \mathrm{~mm} \mathrm{hr}^{-1}$, and $23.8 \pm 10.1 \mathrm{~mm} \mathrm{hr}^{-1}$, at upper, middle, and downstream, respectively.

It is clear from the Table 1 that there was no runoff in a relative flat natural forest ecosystem at upper stream. In agroforestry system, runoff was $0.30 \mathrm{~mm} \mathrm{hr}^{-1}$ and in rainfed agriculture was $0.71 \mathrm{~mm} \mathrm{hr}^{-1}$. It was twice of that on 


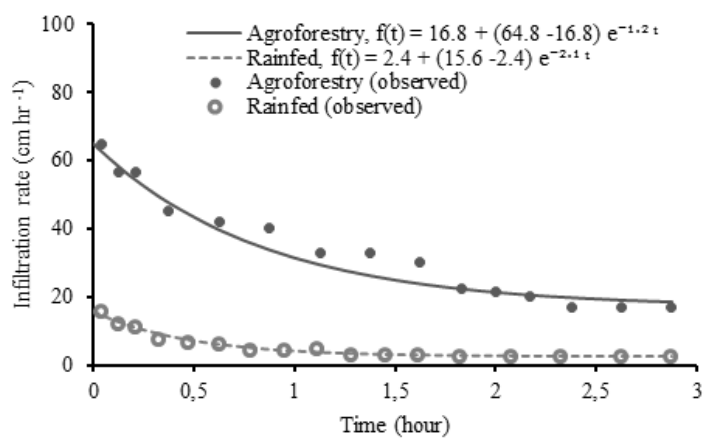

Figure 4 Observed and Hortonian Infiltration model for forest, agroforestry and rainfed in middle stream.

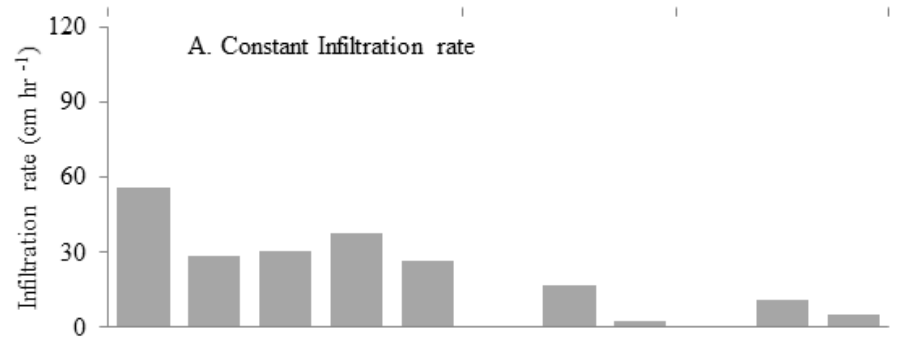

Figure 6 Initial and constant infiltration rate for three study site.

agroforestry. In the middle stream at hillock system, runoff in agroforest was $0.045 \mathrm{~mm} \mathrm{hr}^{-1}$. This figure was a half of runoff in upland agriculture where runoff was $0.098 \mathrm{~mm} \mathrm{hr}^{-1}$. Terraced upland agriculture on hillock formation could prevent runoff, while conventional agroforestry or "kebun" could not effectively prevent runoff on sloppy hillock formation. It is strongly recommended to combine agroforestry and terracing practice on the hillock. The canopy of the vegetation of agroforestry could intercept rain droplets, while terrace could reduce the slope of the land. At downstream, runoff was $0.026 \mathrm{~mm} \mathrm{hr}^{-1}$ in agroforestry and $0.077 \mathrm{~mm} \mathrm{hr}^{-1}$ in rainfed agriculture. It is clear that land with physical borders or bunds has a significant effect on preventing runoff. While, agroforestry system has significant role in sustaining infiltration capacity of soils by preventing soil surface exposure, soil compaction and soil erosion.

The result of this study clearly showed that there had been the impact of land use conversion on runoff and sediment. As it was expected that rainfed agricultural practice presented higher runoff and sediment compared to that of forest and agroforestry system. Sànchez et al. (2002) conducted an experiment in the Venezuelan Andes showed that erosion in the natural forest was $0.43 \mathrm{mg} \mathrm{ha}^{-1}$, which was lower than horticultural crops in rotation $\left(22 \mathrm{mg} \mathrm{ha}^{-1}\right)$, apple tree $(1.96$ $\left.\mathrm{mg} \mathrm{ha}^{-1}\right)$, and pasture without grazing $\left(1.11 \mathrm{mg} \mathrm{ha}^{-1}\right)$. Ngo et

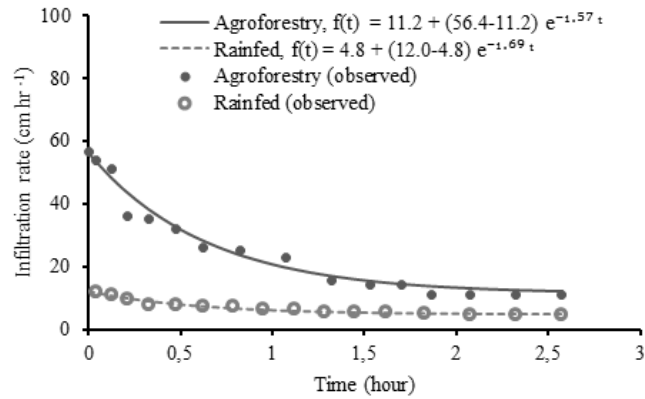

Figure 5 Observed Hortonian Infiltration model for agroforestry and rainfed agriculture in downstream.

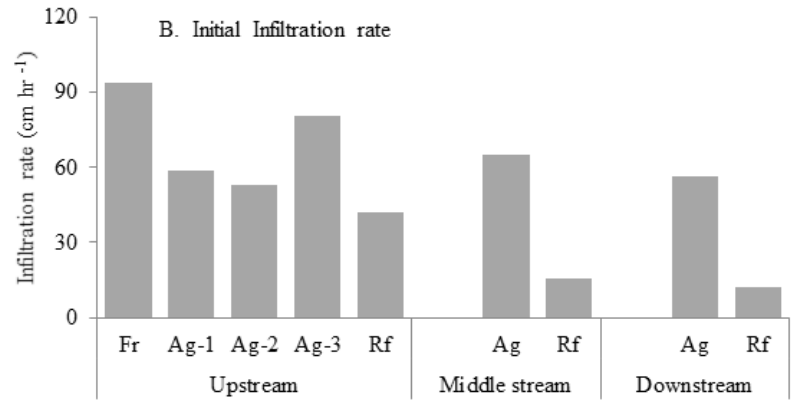

al. (2015) reported that land use change in Da River Basin in Vietnam from forest to field crop and urban area increased annual runoff and sediment, while forest expansion conservation decreased runoff and sediment.

Soil mositure dynamic Table 2 and Tabel 3 show soil moisture dynamic in the forest, agroforestry, and rainfed agriculture at upper, middle, and downstream for dry season (August to October 2014) and rainy season (November 2014-March 2015), and for two soil depths, namely 0-20 cm and $20-40 \mathrm{~cm}$. Soil samples for measuring soil water content was taken every 10 days by using soil driller. The position for successive soil sampling was about $100 \mathrm{~cm}$ apart from the last position of sampling. It moved horizontal and from down to upper.

It can be seen from the Table 2 that in the upstream, soil water content of 0-20 cm depth in the forest was higher than that of agroforestry and rainfed agriculture. At the middle and downstream, soil water content of similar depth in agroforestry was higher than that of rainfed. The pattern of soil moisture dynamic at $0-20 \mathrm{~cm}$ depth was similar to $20-40$ $\mathrm{cm}$ depth. Soil water content in forest ecosystem was higher than that of agroforestry and rainfed agriculture at upstream. Soil water content in agroforestry was always higher than that of upland agriculture at the middle stream and rainfed agriculture at downstream. 
Tabel 1 Runoff for each land use in the upper stream (forest, agroforestry, and rainfed agriculture), in the middle (agroforestry and upland agriculture) and at down stream (agroforestry and rainfed agriculture).

\begin{tabular}{|c|c|c|c|c|}
\hline Site/land use & Average & Maximum & Minimum & Deviation \\
\hline \multicolumn{5}{|l|}{$\begin{array}{l}\text { UPPER STREAM } \\
\text { Site : Aikbual }\end{array}$} \\
\hline Rainfall (mm hr-1) & 29.294 & 67.500 & 13.263 & 11.240 \\
\hline Forest $\left(\mathrm{mm} \mathrm{hr}^{-1}\right)$ & $0.000 \mathrm{a}$ & 0.000 & 0.000 & 0.000 \\
\hline Agroforestry-1 $\left(\mathrm{mm} \mathrm{hr}^{-1}\right)$ & $0.014 \mathrm{ab}$ & 0.086 & 0.000 & 0.021 \\
\hline Agroforestry-2 (mm hr $\left.{ }^{1}\right)$ & $0.030 \mathrm{bc}$ & 0.178 & 0.000 & 0.037 \\
\hline Agroforestry-3 (mm hr-1) & $0.035 \mathrm{c}$ & 0.258 & 0.000 & 0.054 \\
\hline Runoff Rainfed (mm hr-1) & $0.071 \mathrm{~d}$ & 0.441 & 0.015 & 0.091 \\
\hline HSD $5 \%$ & 0.019 & & & \\
\hline \multicolumn{5}{|l|}{$\begin{array}{l}\text { MIDDLE STREAM } \\
\text { Site: Selebung }\end{array}$} \\
\hline Rainfall $\left(\mathrm{mm} \mathrm{hr}^{-1}\right)$ & 37.311 & 56.000 & 14.000 & 10.187 \\
\hline Agroforestry $\left(\mathrm{mm} \mathrm{hr}^{-1}\right)$ & $0.045 \mathrm{a}$ & 0.116 & 0.000 & 0.028 \\
\hline Rainfed $\left(\mathrm{mm} \mathrm{hr}^{-1}\right)$ & $0.098 \mathrm{~b}$ & 0.405 & 0.029 & 0.077 \\
\hline HSD $5 \%$ & 0.017 & & & \\
\hline \multicolumn{5}{|l|}{$\begin{array}{l}\text { DOWNSTREAM } \\
\text { Site: Sukaraja }\end{array}$} \\
\hline Rainfall $\left(\mathrm{mm} \mathrm{hr}^{-1}\right)$ & 23.840 & 44.000 & 10.200 & 10.473 \\
\hline Agroforestry $\left(\mathrm{mm} \mathrm{hr}^{-1}\right)$ & $0.026 \mathrm{a}$ & 0.060 & 0.000 & 0.024 \\
\hline Rainfed $\left(\mathrm{mm} \mathrm{hr}^{-1}\right)$ & $0.077 \mathrm{~b}$ & 0.305 & 0.015 & 0.084 \\
\hline HSD $5 \%$ & 0.016 & & & \\
\hline
\end{tabular}

Tabel 2 Water content in dry season August-October 2014

\begin{tabular}{|c|c|c|c|c|c|c|c|c|}
\hline & \multicolumn{4}{|c|}{ Water content $0-20 \mathrm{~cm}(\%)$} & \multicolumn{4}{|c|}{ Water content $20-40 \mathrm{~cm} \mathrm{( \% )}$} \\
\hline & Average & $\operatorname{Max}$ & Min & Dev & Average & Max & Min & Dev \\
\hline \multicolumn{9}{|l|}{$\begin{array}{l}\text { UPPER STREAM } \\
\text { Site: Aikbual }\end{array}$} \\
\hline Forest $(\%)$ & $32.22 \mathrm{~b}$ & 43.89 & 28.53 & 5.32 & $26.40 \mathrm{~b}$ & 39.30 & 19.92 & 7.06 \\
\hline Agroforestry-1 (\%) & $30.76 \mathrm{~b}$ & 41.36 & 24.27 & 5.82 & $20.25 \mathrm{a}$ & 33.75 & 13.85 & 7.48 \\
\hline Agroforestry-2 (\%) & $29.12 b$ & 39.51 & 24.04 & 5.27 & $20.40 \mathrm{a}$ & 33.61 & 14.97 & 5.97 \\
\hline Agroforestry-3 (\%) & $27.72 \mathrm{ab}$ & 40.79 & 22.23 & 6.38 & $20.37 \mathrm{a}$ & 33.07 & 14.77 & 5.83 \\
\hline Rainfed (\%) & $23.32 \mathrm{a}$ & 34.01 & 16.94 & 5.88 & $16.92 \mathrm{a}$ & 33.22 & 11.01 & 7.46 \\
\hline HSD $5 \%$ & 4.16 & & & & 4.92 & & & \\
\hline \multicolumn{9}{|l|}{$\begin{array}{l}\text { MIDDLE STREAM } \\
\text { Site: Selebung }\end{array}$} \\
\hline Agroforestry (\%) & $14.68 \mathrm{~b}$ & 19.53 & 9.88 & 3.20 & $15.48 \mathrm{~b}$ & 18.33 & 11.50 & 2.32 \\
\hline Rainfed (\%) & 10.76 & 13.54 & 8.07 & 1.87 & 14.12 & 18.60 & 10.15 & 2.66 \\
\hline HSD $5 \%$ & 1.40 & & & & 1.34 & & & \\
\hline \multicolumn{9}{|l|}{$\begin{array}{l}\text { DOWNSTREAM } \\
\text { Site: Sukaraja }\end{array}$} \\
\hline Agroforestry (\%) & $16.67 \mathrm{~b}$ & 21.47 & 11.54 & 3.20 & $20.03 \mathrm{~b}$ & 23.80 & 16.03 & 2.50 \\
\hline Rainfed (\%) & 13.19 & 19.00 & 9.96 & 2.99 & 18.33 & 22.07 & 13.29 & 2.76 \\
\hline HSD 5\% & 1.66 & & & & 1.41 & & & \\
\hline
\end{tabular}


Tabel 3 Water content in rainy season November 2014-March 2015

\begin{tabular}{|c|c|c|c|c|c|c|c|c|}
\hline & \multicolumn{4}{|c|}{ Water content $0-20 \mathrm{~cm}(\%)$} & \multicolumn{4}{|c|}{ Water content $0-20 \mathrm{~cm}(\%)$} \\
\hline & Average & Max & Min & Dev & Average & $\operatorname{Max}$ & Min & Dev \\
\hline \multicolumn{9}{|l|}{$\begin{array}{l}\text { UPPER STREAM } \\
\text { Site: Aikbual }\end{array}$} \\
\hline Forest $(\%)$ & $56.70 \mathrm{~b}$ & 65.10 & 52.37 & 4.36 & $56.93 \mathrm{c}$ & 63.80 & 50.50 & 4.87 \\
\hline Agroforestry-1 (\%) & $54.28 \mathrm{a}$ & 60.97 & 50.64 & 3.78 & $51.90 \mathrm{~b}$ & 56.47 & 48.20 & 2.76 \\
\hline Agroforestry-2 (\%) & $54.51 \mathrm{ab}$ & 62.80 & 50.33 & 4.18 & $50.49 \mathrm{ab}$ & 54.23 & 48.73 & 1.75 \\
\hline Agroforestry-3 (\%) & $54.68 \mathrm{ab}$ & 61.37 & 49.97 & 3.74 & $51.33 \mathrm{a}$ & 56.67 & 48.40 & 2.41 \\
\hline Rainfed (\%) & $52.73 \mathrm{a}$ & 59.70 & 46.67 & 4.15 & $50.09 \mathrm{a}$ & 53.53 & 47.33 & 1.68 \\
\hline HSD $5 \%$ & 2.24 & & & & 1.62 & & & \\
\hline \multicolumn{9}{|l|}{$\begin{array}{l}\text { MIDDLE STREAM } \\
\text { Site: Selebung }\end{array}$} \\
\hline Agroforestry (\%) & $49.29 \mathrm{~b}$ & 52.27 & 40.03 & 4.07 & $51.57 \mathrm{~b}$ & 54.80 & 41.93 & 3.56 \\
\hline Rainfed (\%) & $47.43 \mathrm{a}$ & 50.87 & 39.23 & 3.86 & $50.11 \mathrm{a}$ & 54.60 & 41.37 & 3.31 \\
\hline HSD $5 \%$ & 1.61 & & & & 1.39 & & & \\
\hline \multicolumn{9}{|l|}{$\begin{array}{l}\text { DOWNSTREAM } \\
\text { Site: Sukaraja }\end{array}$} \\
\hline Agroforestry (\%) & $50.12 \mathrm{~b}$ & 54.53 & 44.70 & 2.66 & $53.18 \mathrm{~b}$ & 55.80 & 50.53 & 1.50 \\
\hline Rainfed (\%) & $47.41 \mathrm{a}$ & 52.47 & 40.33 & 3.73 & $51.40 \mathrm{a}$ & 55.00 & 48.87 & 1.73 \\
\hline HSD 5\% & 1.31 & & & & 0.65 & & & \\
\hline
\end{tabular}

It is obvious that soil water content during the dry season was lower than that of the rainy season (Table 2 and Table 3 ). This finding stated that natural forest was the best ecosystem in term of soil moisture conservation. It was possible for agroforestry to conserve soil moisture during wet and dry seasons. Shifting from forest system to either upland agriculture or rainfed agriculture would result in decreasing the capacity of soils to conserve moisture. Haque et al. (2014) presented that soil moisture content, water holding capacity of deforested sites was lower than that of forest sites.

Variation of soil water content under forest, agroforestry and rainfed associated to different in soil properties and land use. Soil texture in the forest, agroforestry and rainfed at upper was loam to sandy loam with coarse material of pumice stones. Soil texture in agroforestry, and rained in the middle is clay loam, and agroforestry and rainfed at downstreamwas clay. Soil bulk density (BD) of the soils was similar for each site. Soil organic matter in the forest, agroforestry and rainfed at the upper was $6.8 \%, 5.0 \%$, and $3.5 \%$, respectively, while for agroforestry and rained at the middle was $3.5 \%$ and $2.7 \%$, in agroforestry and rainfed at downstream was $2.5 \%$ and $1.7 \%$, respectively.

The result of this study showed that land cover affected soil moisture status. Wang et al. (2012) which conducted soil moisture monitoring during the growing season in Loess Plateau in northern China showed that soil moisture under the corn was higher than that of grass, shrubs, and plantation forest. D'Odorico et al. (2007) stated that soil moisture under canopy was higher than that in inter canopy space, though soon after rainfall soil moisture in the inter canopy are wetter to that of under canopy. Investigation of spatial and temporal variation of soil moisture in silvopastoral of Loess Plateau in the Province of west Shanxi showed that soil moisture content both in grass land and forest land decreased by increasing soil depth (Lei et al. 2011).

\section{Conclusion}

Land use and land cover change from natural forest to either agroforestry or rainfed agriculture with cash crops at upper stream of Renggung Catchment had significantly reduced infiltration capacity of soils; from $56.6 \mathrm{~cm} \mathrm{hr}^{-1}$ (in the forest) to $28.8 \mathrm{~cm} \mathrm{hr}^{-1}$ in agroforestry of 10-15 years old, to $30.0 \mathrm{~cm} \mathrm{hr}^{-1}$ in $15-30$ years agroforestry, and to $37.8 \mathrm{~cm} \mathrm{hr}^{-1}$ in $>30$ years agroforestry. There was more than half capacity of soil infiltration rate had lost due to converting the natural forest into rainfed agriculture that was $26.4 \mathrm{~cm} \mathrm{hr}^{-1}$. High capacity of soil infiltration in the natural forest at upper stream resulted in zero runoff. Agroforestry system could serve for better soil infiltration of inceptisols on hillocks formation at the middle stream and of heavy clay vertisols at downstream. The capacity of agroforestry system in preventing runoff was in between forest and rainfed agriculture. The natural forest and long-term established of agroforestry had potential capacity to conserve soil moisture at the level of 0 to $40 \mathrm{~cm}$ soil depth during the dry season. There was unfortunately that soil moisture in rainfed agriculture continually depleted to the level of a wilting point during a peak of the dry season. At middle and downstream, soil water content for both depths was significantly higher in agroforestry compared to that of rainfed. Overall, results of the study could be considered as an empirical and scientific proof that agroforestry would be an acceptable practice in sustaining hydrology cycle and soil water conservation in the watershed.

\section{Acknowledgment}

It is to honestly acknowledge that research was fully supported by Fauna Flora International (FFI) and PT Export Leaf Indonesia (PT ELI) as a part of 'the watershed protection project in Lombok", Eastern Indonesia. 


\section{References}

Achard F, Ebeuchle R, Mayaux P, Stibig HU, Bodart C, Brink A,Carboni S, Desclee B, Donnay F, Eva HD, Lupi A, Rasi R, Seliger R, Simonetti A. 2014. Determination of tropical deforestation rates and related carbon losses from 1990 to 2010. Global Change Biology 20:2540-2554. http://dx.doi.org/10.1111/gcb.12605.

Agnese C, Bagarello V, Baiamonte G, Iovino M. 2011. Comparing physical quality of forest and pasture soils in a Sicilian watershed. Soil Science Society of America Journal 75:1958-1970. http://dx.doi.org/10.2136/sssaj 2011.0044

As-syakur AB. 2009. Evaluasi zona agroklimat dari klasifikasi Schmidt-ferguson menggunakan aplikasi Sistem Informasi Geografis (SIG). Jurnal Pijar MIPA (Pengkajian Ilmu dan Pengajaran Matematika dan Ilmu Pengetahuan Alam) 3 (1):17-22.

Bowler D, Buyung-Ali L, Healey JR, Jones JPG, Knight T, and Pullin AS. 2010. The evidence base for community forest management as a mechanism for supplying global environmental benefits and improving local welfare: A STAP advisory document. Centre for Evidence-Based Conservation. SENRGY. Bangor University. Bangor. UK.

Bruijnzeel LA. 2004. Hydrological functions of tropical forests: not seeing the soil for the trees? Agriculture, Ecosystems and Environment 104:185-228. http://dx.doi. org/10.1016/j.agee.2004.01.015.

Busch J, Engelmann J. 2015. The future of forests: emissions from tropical deforestation with and without a carbon price, 2016-2050. CGD Working Paper 411. Washington, DC: Center for Global Development. http://www.cgdev.org/publication/future-forestsemissions-tropical-deforestation-carbon-price.

Cramer W, Bondeau A, Schaphoff S, Lucht W, Smith B, Sitch S. 2004. Tropical forests and the global carbon cycle: impacts of atmospheric carbon dioxide, climate change, and rate of deforestation. Philosophical Transaction of The Royal Society B 359:331-343. http://dx.doi.org/10. 1098/rstb.2003.1428.

D'Odorico P, Caylor K,Okin GS, Todd M, Scanlon TM. 2007. On soil moisture- vegetation feedbacks and their possible effects on the dynamics of dryland ecosystems. Journal of Geophysical Research 112:G04010. http://dx.doi.org/10. 1029/2006JG000379.

Hajabbasi MA, Jalalian A, Karimzadeh HR. 1997. Deforestation effects on soil physical and chemical properties, Lordegan, Iran. Plant and Soil 190:301-308. http://dx.doi.org/10.1023/A:1004243702208.

Haque SMS, Gupta SD, Miah S. 2014. Deforestation effects on biological and other important soil properties in an upland watershed of Bangladesh. Journal of Forestry Research 25(4):877-885. http://dx.doi.org/10.1007

\section{/s11676-014-0534-2.}

George N, Killur RRB, Cornelio DL. 2013. Land use conversion and soil properties in a lowland tropical landscape of Papua New Guinea. Jurnal Manajemen Hutan Tropika19(1):39-45. http://dx.doi.org/ 10.7226/jtfm.19.1.39.

Horton RE. 1941. An approach toward a physical interpretation of infiltration-capacity. Soil Science Society of America Journal 5:399-417. http://dx.doi.org/ 10.2136/sssaj1941.036159950005000C0075x.

Ilstedt U, Malmer A, Verbeeten E, Murdiyarso D. 2007. The effect of afforestation on water infiltration in the tropics: A systematic review and meta-analysis. Forest Ecology and Management 251: 45-51. http://dx.doi.org/10.1016/ j.foreco.2007.06.014.

Indrarto GB, Murharjanti P, Khatarina J, Pulungan I, Ivalerina F, Rahman J, Prana M. N, Resosudarmo IAP, Muharrom E. 2012. The context of REDD+ in Indonesia: Drivers, agents and institutions. Working Paper 92. CIFOR. Bogor. Indonesia.

Kaskoyo H, Mohammed AJ, Inoue M. 2014. Present state of community forestry (Hutan Kemasyarakatan/HKm) program in a protection forest and its challenges: Case study in Lampung Province, Indonesia. Journal of Forest Science 30(1):15-29. http://dx.doi.org/10.7747/ JFS.2014.30.1.15.

Lawrence D,Vandecar K. 2015. Effects of tropical deforestation on climate and agriculture. Nature Climate Change 5:27-36. http://dx.doi.org/10.1038/nclimate2430.

Lei Y, Lubo G, Huaxing B,Qingke Z, Xiaoyan W. 2011. Spatio-temporal dynamics of soil moisture in silvopastoral system in the Loess Plateau of west Shanxi province. Procedia Environmental Sciences 8:153 160.http://dx.doi.org/10. 1016/j.proenv.2011.10.025.

Lili M, Bralts VF, Yinghua P, Han L, Tingwu L. 2008. Methods for measuring soil infiltration: State of the art. International Journal of Agricultural and Biological Engineering 1(1):22-30. http://dx.doi.org/ 10.3965/ j.issn.1934-6344.2008.01.022-030.

Mahmoud SH, Alazba AA. 2015. Hydrological response to land cover changes and human activities in arid regions using a Geographic Information System and Remote Sensing. PLOS ONE 10(4):e0125805. http://dx.doi.org/10. 1371/journal.pone.0125805.

Moehansyah H, Maheshwari BL, Armstrong J. 2002. Impact of land-use changes and sedimentation on the Muhammad Nur Reservoir, South Kalimantan, Indonesia. JSS-J Soils \& Sediments 2(1):9-18. http://dx.doi.org/10.1007/ BF02991245.

Ngo TS, Nguyen DB, Shrestha RP. 2015. Effect of land use 
change on runoff and sediment yield in Da River Basin of Hoa Binh Province, Northwest Vietnam. Journal of Mountain Science 12(4):1051-1064. http://dx.doi.org/ 10.1007/s11629-013-2925-9.

Pirastru M, Castellini M, Giadrossich F, Niedda M. 2013. Comparing the hydraulic properties of forested and grassed soils on an experimental hillslope in a Mediterranean Environment. Procedia Environmental Sciences 19:341-350. http://dx.doi.org/10.1016/ j.proenv.2013.06.039.

Porter-Bolland L, Ellis EA, Guariguata MR, Ruiz-Mallén I, Negrete-Yankelevich S, Reyes-García V. 2012. Community managed forests and forest protected areas: An assessment of their conservation effectiveness across the tropics. Forest Ecology and Management 268:6-17. http://dx.doi.org/10.1016/j.foreco.2011.05.034.

Price K, Jackson CR, Parker AJ. 2010. Variation of surficial soil hydraulic properties across land uses in the southern Blue Ridge Mountains, North Carolina, USA. Journal of Hydrology 383:256-268. http://dx.doi.org/10.1016/j. jhydrol.2009.12.041.

Sànchez LA, Ataroff M, López R. 2002. Soil erosion under different vegetation covers in the Venezuelan Andes. The Environmentalist 22:161-172. http://dx.doi.org/10.1023/ A:1015389918416.

Shit PK, Bhunia GS, Maiti R. 2014. Vegetation Influence on runoff and sediment yield in the lateritic region: An experimental study. Geography \& Natural Disasters 4(1):1-9. http://dx.doi.org/10.4172/2167-0587.1000116.
Shougrakpam S, Sarker R, Dutta S. 2010. An experimental investigation to characterise soil macroporosity under diferent land use and land covers of northeast India. Journal of Earth System Science 119(5):655-674. http://dx.doi.org/10.1007/s12040-010-0042-5.

Straaten OV, Corre MD, Wolf K, Tchienkoua M, Cuellar E, Matthews RB, Veldkamp E. 2015. Conversion of lowland tropical forests to tree cash crop plantations loses up to onehalf of stored soil organic carbon. PNAS 112(32):9956-9960. http://dx.doi.org/10.1073/pnas. 1504628112 .

Suryatmojo H. 2014. Recovery of Forest Soil Disturbance in the intensive forest management system. Procedia Environmental Sciences 20:832-840. http://dx.doi.org/ 10.1016/j.proenv.2014.03.101.

Soil Survey Staff. 2014. Keys to Soil Taxonomy. Twelfth Edition. USA: The United States Department of Agriculture.

Wang S, Fu BJ, Gao GY, Yao XL, Zhou J. 2012. Soil moisture and evapotranspiration of different land cover types in the Loess Plateau, China. Hydrology and Earth System Sciences 16:2883-2892. http://dx.doi.org/10.5194/ hess16-2883-2012.

Wang L, Zhong C, Gao P, Xi W, Zhang S. 2015. Soil infiltration characteristics in agroforestry systems and their relationships with the temporal distribution of rainfall on the Loess Plateau in China. PLoS ONE 10(4): e0124767. http://dx.doi.org/10.1371/journal.pone. 0124767. 